\title{
都市部における RTK-GPS の信頼性向上*1 RTK-GPS Reliability Improvement in Dense Urban Areas
}

\author{
白井友子*2. 久保信 明*2 \\ Tomoko SHIRAI and Nobuaki KuBo
}

Key Words : RTK-GPS, Ratio Test, Reliability

\begin{abstract}
It is expected that the use of GNSS technology in urban areas will be increased. Since there are many buildings in urban areas, the direct signal from satellite occasionally can be reflected or diffracted. As a result, we are faced with big errors due to multipath. It is strongly required to improve reliability considering the use of GNSS for future ITS. In order to do that, the ability to detect the inferior observations of GNSS is required. The objective of this paper is to improve reliability and availability in RTK-GPS. Firstly, this study reveals the relationships between reliability and availability according to the quality check of GPS observation data. For example, reliability decreases when the measurement calculation is done with four numbers of satellites compared with five numbers or more of satellites. Then the detection algorithm to remove the inferior observations of GPS is proposed. The performance was checked by using raw GPS data obtained in major cities and it is confirmed that the performance was improved by using our proposed method.
\end{abstract}

\section{1. は じめ に}

RTK-GPS (Real-Time Kinematic GPS) は数 $\mathrm{cm} の$ 精 度で，瞬時に位置決定が可能な測位システムである。現在， 測量や地殼変動推定など, 静止点や周囲に電波を遮るもの が少ないところで多く利用されている. 今後は ITS (Intelligent Transport Systems) や精密農業など，移動体や周 囲に電波を遮る建物の多い場所, 都市部での積極的な利用 が期待される. ITS は道路交通が抱える事故や渋滞, 環境 対策など，様々な課題を解決するためのシステムとして考 えられている。移動体の制御支援に RTK-GPS を利用す る場合, 正確な位置情報を入手することが重要となる。本 研究では，都市部におけるRTK-GPS の信頼性向上を目的 とした. RTK 測位で重要となるアンビギュイテイ決定に は, アンビギュイテイ探索手法の 1 つとして確立している LAMBDA 法1) (Least-square Ambiguity Decorrelation Adjustment）とRatio テスト2) を利用した。信頼性向上 のため, 具体的には, Ratio テストや信号強度, 可視衛星 数などが測位精度に与える影響について報告する。本論文 の流れは以下の通りである。まず，RTK-GPS 測位の概要 と都市部での現在の性能について述べ, 提案する手法とし て信号強度や可視衛星数に着目した方法を述べた. 次に名 古屋, 丸の内, 月島の 3 力所において行った実験結果と考 察を述べ, 都市部移動体での信頼性や利便性についてまと めた。

\footnotetext{
*1 (C) 2012 日本航空宇宙学会

平成 23 年 6 月 17 日原稿受付

*2 東京海洋大学
}

\section{RTK-GPS の概要と現状}

2.1 RTK-GPS の概要 本研究では 2 周波の観測デー 夕を用いており，L1 帯と L2 帯の信号を受信する。衛星側 と受信機側の時計誤差を消去する二重差の観測方程式を用 いた。また，アンビギュイティ決定にはLAMBDA 法を使 い，推定されたアンビギュイティを検証するため Ratio テ ストを利用した。通常, Ratio テストの值が 3 以上であれ ば FIX 解と判定される ${ }^{3)}$. しかしこの定数 3 についての明 確な統計的, 確率的な基準はなく目安に過ぎない.

ITS の利用を考慮した場合, 道路や自動車の大きさな どから水平誤差 $1 \mathrm{~m}$ 以内程度が最低の条件となってくる. そのため, 本研究では測位回数に対して FIX 解が求められ た割合を利便性とし，すべての FIX 解のうち水平絶対誤差 $1 \mathrm{~m}$ 以内である割合を信頼度として計算した. Ratio テスト を満たし，FIX 解と判定されたにもかかわらず，水平誤差 $1 \mathrm{~m}$ 以上となるミス FIX の判定には, POSLV ${ }^{4)}$ (ニコン・ トリンブル社) で算出される精密位置を利用した. POSLV の方式は慣性計測装置, 距離計測指標, GPS を利用してお り, 数 $\mathrm{cm}$ 程度の精度で常時測位可能である.メーカーの公 称位置精度は, 本論文の実験場所においても $10 \mathrm{~cm}$ 以内で あった.よって FIX 解の誤差と見なしている值に, POSLV の誤差は $10 \mathrm{~cm}$ 以内程度見積もられる. 第 1 図に本研究に おける信頼度チェック手順をフローチャートにしてまとめた.

まず，衛星ごとに観測データ品質チェックを行い，測位 に利用する衛星を決定する。品質チェックの結果, 衛星数 が 4 機以上であれば測位計算可能であるが，衛星配置によ り誤差が異なるので, HDOP のチェックも行う。測位計算 可能であれば, LAMBDA 法によりアンビギュイティ決定 を行い，Ratioテストにより FIX 判定を行う。本論文では， 


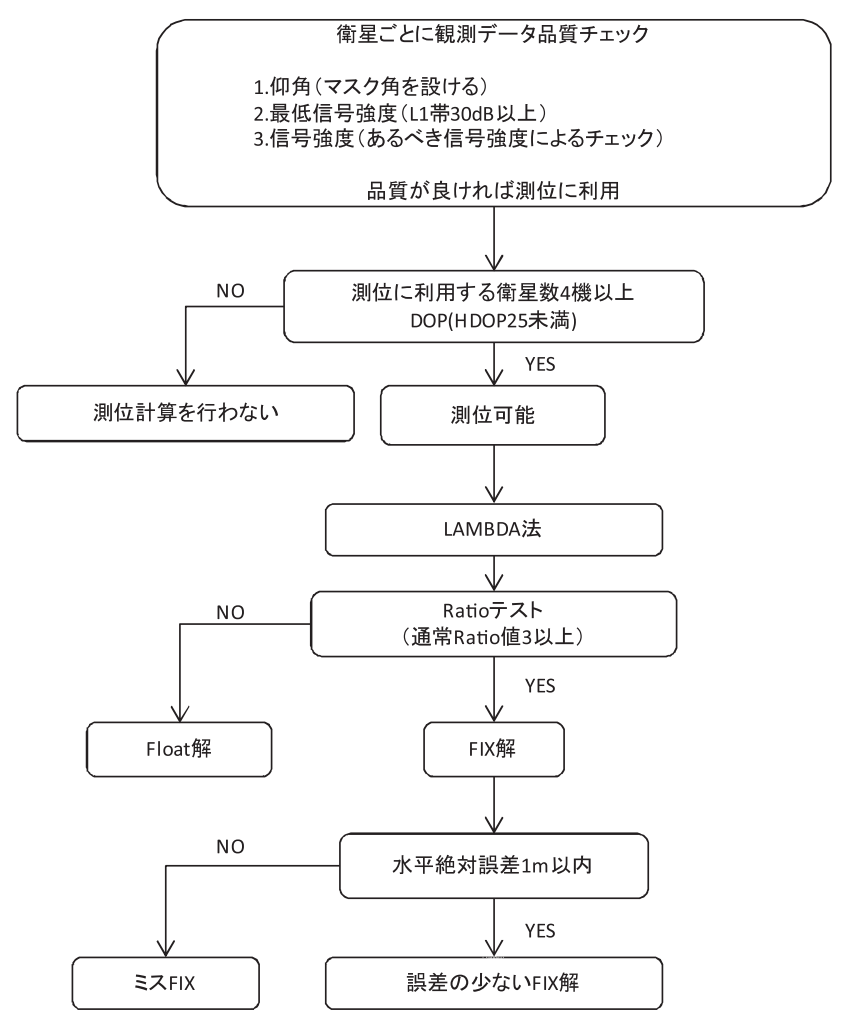

第 1 図 信頼度チェックのフローチャート

Float 解を利用せず，FIX 解と擬似距離の DGPS 解を用い た.その理由は, 1 エポック（1 回の観測）ごとにアンビ ギュイティを推定し, 測位解を算出する場合, これまでの 実験結果より, Float 解の精度はDGPS の精度とあまり变 わらなかったためである. また, 都市部での Float 解の精 度は $1 \mathrm{~m}$ を超えることも多く, 多少ミス FIX があったとし ても FIX 解を用いる方が，精度が良いと考えた１エポッ クごとにアンビギュイティを推定する理由は, 都市部移動 体では時々刻々と周囲の環境が变化し, 電波の遮蔽と受信 が繰り返されるため, サイクルスリップ等が頻発した場合 でも，その影響を受けないようにすることができるからで ある。ただし，搬送波位相のトラッキングがある程度継続 できる場合は, 常に 1 エポックで解く必要はなく, バラン スが重要であるといえるが, 本稿ではすべての実験で 1 エ ポックでの性能を調査した. 最後にPOSLVの精密位置と 比較し, ミス FIX と誤差の少ないFIX 解の判別を行う.こ の手順を全エポックに行った後, 利便性と信頼性の評価を 行う.

2.2 RTK 測位の現状 都市部では周囲の建物により 上空の視界が大きく異なるため, 衛星からの電波が遮断さ れたり, マルチパスの影響を受けやすくなっている. RTK 測位の現状を示すため, 測位環境の異なる 2 力所の静止点 (屋上とビル付近) において 12 時間 $1 \mathrm{~Hz}$ データを取得し た。基線長は 2 地点ともに $1 \mathrm{~km}$ 未満であった。 2 地点の 上空視界を魚眼レンズで撮影したものを第 2 図に示す.ビ ル付近での測位環境が都市部での測位環境に類似している と考えられる。そのため, 屋上に比べビル付近では利便性,

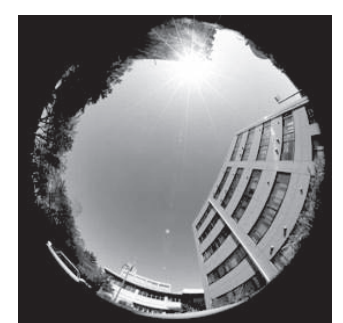

ビル付近

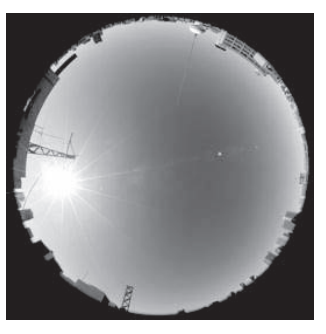

屋上
第 2 図 都市部と屋上の上空視野

第 1 表 観測地点別, 信頼性と利便性

\begin{tabular}{lcc}
\hline 観測地点 & 利便性 & 信頼性 \\
\hline 屋上 & $43200 / 43200$ & $42862 / 43200$ \\
& $(100 \%)$ & $(99.2 \%)$ \\
ビル付近 & $12075 / 43200$ & $11519 / 12075$ \\
& $(28.0 \%)$ & $(88.9 \%)$ \\
\hline
\end{tabular}

信頼性ともに低下することが予想される．測位結果を第 1 表にまとめた。この表において，利便性は測位回数に対し て FIX 解が求められた割合，信頼性はすべての FIX 解の うち水平誤差 $1 \mathrm{~m}$ 以内である割合を示している。また，利 便性の分母は全測位回数, 分子は FIX 回数を示し, 信頼性 の分母は FIX 回数, 分子は FIX 解のうち水平䛊差 $1 \mathrm{~m}$ 以 内であった測位回数を示している. 観測データ品質チェッ クは最低信号強度（L1 帯の信号強度 $30 \mathrm{~dB}$ 以上）と, マ スク角 10 度の条件で行っている。屋上においては測位回 数 43200 回のうち全エポックで FIX 解を得ることができ た。そのため, 利便性は $100 \%$ となった。また, FIX 解の うち水平誤差 $1 \mathrm{~m}$ 以内の割合は $99.2 \%$ あった。一方で, ビル付近の都市部に近い環境においては利便性 $28 \%$, 信頼 性 $88.9 \%$ となった。

屋上での結果に比べ，ビル付近では利便性は 3 分の 1 以 下となり，信頼性も $90 \%$ に満たないことがわかる. 利便性, 信頼性は主に 3 つの理由により低下したと考えられる。1 つは反射波や回折波などマルチパスの影響である。もう 1 つは電波を遮断されたことによる可視衛星数の減少. そし て, 衛星配置によるDOP の増加である。ここでは静止点 での性能を示したが, 移動体でも同様に, 都市部では RTK 測位の性能が格段に低下することが予想される。

RTK-GPS の現状をチェックするため本解析では名古屋, 丸の内, 月島の 3 カ所でデー夕を取得した. 名古屋駅周辺 や丸の内では高層ビルが多く, 性能が月島より悪くなるこ とが予想される。

\section{RTK-GPS の信頼性}

衛星測位の精度は測距誤差と衛星配置によって決まる。測 距誤差の主な原因は短基線の場合, 観測データに含まれる マルチパスの影響である，そのため，あるべき信号強度に よるチェックとマスク角の設定を行うことで観測データの 信頼度を向上させる. 衛星配置は DOP としてよく知られ ている。本実験では水平誤差を重視しているため, HDOP をチェックする。 
また，観測データに含まれる誤差により，アンビギュイ ティ決定に利用する LAMBDA 法と Ratio テストにも影響 がでる。このことを国土地理院のデータを用いて次の 3.1 節に示す.

\section{1 観測データの品質とミス FIX の関係 ミス FIX} とは, Ratioテストを満たし FIX 解と判定されたにもかか わらず，アンビギュイテイが正しく推定されなかったため, 誤差の大きい測位結果を意味する。国土地理院の電子基準 点観測データを用いて可視衛星数に対するRatio テストの 閾值とその測位結果の信頼性を調査した. 電子基準点は測 量における基準点, 観測点の 1 つであり, 周囲に電波を遮 るものが少なく高精度 GPS 受信機を利用している. Ratio テストの間值における信頼性を測位衛星数ごとに第 3,4 図 で示した．横軸は Ratio テストの閾值，縦軸は信頼性（\%) を示している. Ratio テストの閾值は例えば 2 であれば 2 以上を FIX 解と判定することを意味する. Ratio テストの 值は, LAMBDA 法により推定されたアンビギュイティの 最善解と次善解の残差の比である (Ratio テストの值 $=$ 次 善解の残差 $\div$ 最善解の残差). そのため, Ratio テストの䦨 值を 1 以上に設定することは, 残差の比の大きさにかかわ らず，最善解を必ずFIX 解とみなすことを意味する．第 3 図は基線長 $9 \mathrm{~km}$ である場合に対し，第 4 図は基線長 $3 \mathrm{~km}$ の場合の結果を示す. 電子基準点は周囲に衛星からの電波 を遮断する建物が少ないため可視衛星数が多い. 本稿では, 可視衛星数が少ない場合を検討しているためマスク角を 30 度とした。

基線長に関係なく，可視衛星数 5 機以上である場合は Ratio テストの值が 1.5 以上であれば十分な信頼度が得られる

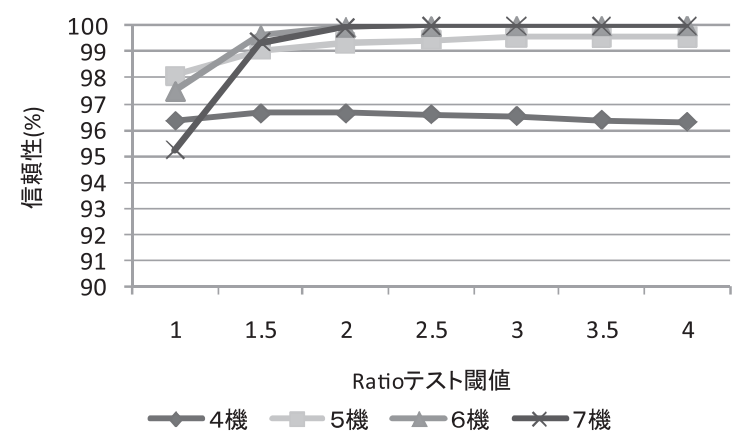

第 3 図 信頼性と Ratio 閾值（基線長 $9 \mathrm{~km}$ )

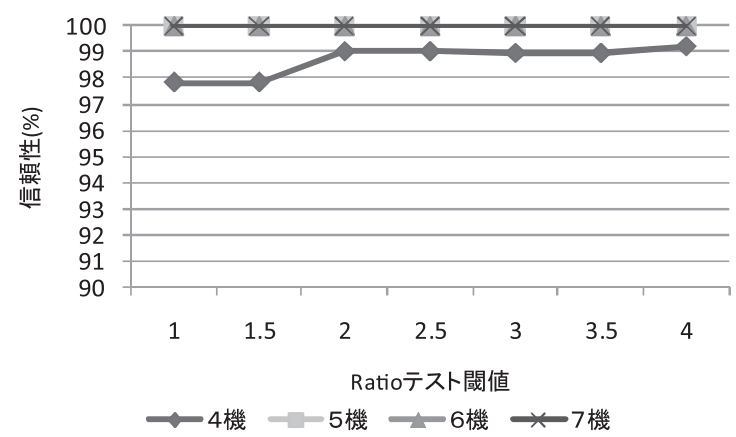

第 4 図 信頼性と Ratio 閾值（基線長 $3 \mathrm{~km}$ )
ことがわかる．また，第 4 図から衛星数 5 機以上の場合，基 線長が短く, 電離層が安定していて国土地理院の観測点で ある場合, Ratio テストは必要ないレベルであることがわ かる. 一方で可視衛星数 4 機である場合, 基線長の距離に より信頼性が低下することが読み取れる，基線長が長いほ ど主に電離層のバイアスの影響を受けることが知られてい る. 衛星の仰角にもよるが, 電離層遅延量による誤差は基 線長 $10 \mathrm{~km}$ において約 $1 \mathrm{~cm}$ 程度の誤差が含まれる ${ }^{5)} .1 \mathrm{~cm}$ 程度のノイズが衛星数 4 機で計算を行う場合, LAMBDA 法と Ratio テストに大きな影響を与えると考えられる.

このことから，アンビギュイテイ探索手法として利用し た LAMBDA 法と Ratio テストは可視衛星数 4 機の場合, わずかな測距誤差であっても影響を受けやすいため, 誤差 が少ない観測デー夕を利用するとより正確なアンビギュイ ティ決定が可能となることがわかる.

3.2 観測データの品質チェック 観測データの品質チェッ クは従来のマスク角と最低信号強度 (L1 帯の信号強度 $30 \mathrm{~dB}$ 以上）の他に，「あるべき信号強度によるチェック」6)を行う.

「あるべき信号強度によるチェック」は，すでに 2004 年に 提案されている手法である。 以下にアルゴリズムの概要を 説明する。周囲の開けた場所において, 長時間の GPS デー 夕を取得すると, 同機種の受信機, アンテナ及びケーブル を用いることにより，仰角と信号強度の一定の関係が明ら かになる、その結果を第 5 図に示した。この図より，仰角 を決定すると, 本来あるべき信号強度を求めることができ ることがわかる，もしマルチパスや回折等の影響を衛星が 受けている場合, その衛星の信号強度は, 上記のラインよ りも低くなるケースがほとんどである。よって，上記のラ インよりある閾值以下の信号強度の衛星を, 測位に利用し ないと判断するのが本手法である。本稿では, LAMBDA 法が前節 3.1 からわかるように, 観測デー夕誤差に敏感な

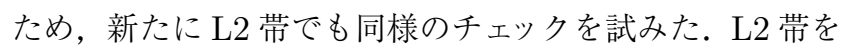
チェックすることで, より誤差の少ない観測データを使用 できると考えられる。

次節では，L1 帯でのみチェックを行う場合と L1, L2 帯 両方に利用した場合，本手法を L1, L2 ともに利用しない 場合について検証実験を行ったので報告する.

また, 都市部においてはたくさんの高層ビルが電波環境に

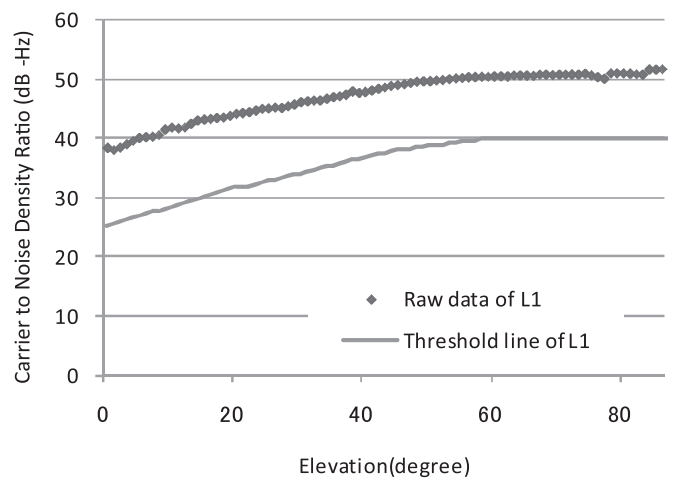

第 5 図 L1 帯の信号強度と仰角の関係 
複雑な影響を与えるため7)，あるべき信号強度によるチェッ クでも，観測データの品質を維持できないケースも見られ る。そこで，さらにマスク角による制限を厳しくしたケー スの評価も試みた。例えば 6 機以上の衛星から電波を受信 できる場合でも Ratio テストの值が低く，FIX と判定され ない場合がある. 可視衛星数が多いにもかかわらず Ratio テストを満たさなかったエポックが，マスク角や信号強度 のチェックにより品質チェックを厳しくして測位計算するこ とで, Ratio テストの值が大きくなり, FIX 解となること がある。そのため，観測データチェックを厳しくすること で利便性が向上することもある。

可視衛星数，信号強度，マスク角の信頼度に影響する 3 つのパラメータについて述べたが, 衛星数を 5 機以上に保 つことが, 第 $3 ４$ 図の結果からも, 信頼性向上にはきわめ て重要である. 衛星数が 5 機以上である場合 Ratio テス卜 を満たした FIX 解は $99 \%$ 以上の割合で水平誤差 $1 \mathrm{~m}$ 以内 の測位が可能である。また, 観測データチェックを厳しく することで, 利便性と信頼性ともに向上するが, 衛星数 4 機で測位を行う回数が増加すると, Ratio テストでの信頼 度が低下することや HDOP の増加が原因となり, 結果と して信頼性の低下につながることにも注意しなければなら ない.

\section{4. 実験結果及び考察}

前節で述べた内容について実際に名古屋, 丸の内, 月島 の 3 カ所でデー夕を取得した.

4.1 名古屋駅周辺実験 2010 年 5 月 6 日に名古屋駅周 辺を車で走行し, $10 \mathrm{~Hz}$ で 30 分程度 GPS デー夕を取得し た。受信機は基準局と車側ともに 2 周波の高精度受信機で 基線長は $2 \mathrm{~km}$ 程度であった。周囲は高層ビルに囲まれる 場所や高架下もある. 第 6 図に走行経路を示した. 真值と して前述の POSLVを利用した。

第 2,3 表に結果を示す．表の見方は第 1 表と同様であ る. 第 2 表はマスク角 10 度でそれぞれ「あるべき信号強度 によるチェック」を利用しなかった場合と L1 带のみに利用 した場合，L1，L2 带両方に利用した場合の結果である。第 3 表はマスク角 30 度の場合である. あるべき信号強度によ るチェックを行わなかった場合でも最低信号強度（L1 带の 信号強度 $30 \mathrm{~dB}$ 以上）によるチェックは行っている。また, 第 7 図にマスク角 30 度，あるべき信号強度によるチェック を行わなかった場合の衛星数ごとの信頼性を示す. 図の見 方は第 3 図と同様である.

あるべき信号強度によるチェックを L1，L2 帯に行い，観 測データの品質チェックを厳しくすることで信頼性が向上 した. 16300 回測位回数のうち, マスク角 30 度とした場合 FIX 回数最大となり, 利便性 $16 \%$ となった。この結果から 名古屋のような都心部ではマルチパスの影響が少ないと考 えられる高仰角の衛星を測位計算に用いることで RTK の 利便性が向上することがわかる. しかし，L1，L2 带両方 に利用しマスク角 30 度の場合, マスク角 10 度に比べて信 頼性が低下している。

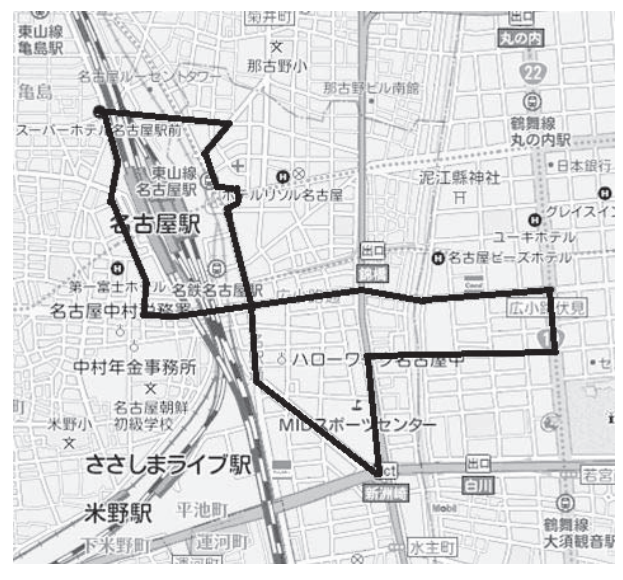

第 6 図 名古屋駅周辺での走行経路概要

第 2 表 マスク角 10 度の場合

\begin{tabular}{ccc}
\hline $\begin{array}{c}\text { あるべき信号強度による } \\
\text { チェック利用信号 }\end{array}$ & 利便性 & 信頼性 \\
\hline なし & $2055 / 16300$ & $1828 / 2055$ \\
& $(12.6 \%)$ & $(89.0 \%)$ \\
L1 のみ & $1998 / 16300$ & $1875 / 1998$ \\
& $(12.3 \%)$ & $(93.8 \%)$ \\
L1+L2 & $1976 / 16300$ & $1922 / 1976$ \\
& $(12.1 \%)$ & $(97.3 \%)$ \\
\hline
\end{tabular}

第 3 表 マスク角 30 度の場合

\begin{tabular}{ccc}
\hline $\begin{array}{c}\text { あるべき信号強度による } \\
\text { チェック利用信号 }\end{array}$ & 利便性 & 信頼性 \\
\hline なし & $2709 / 16300$ & $2444 / 2709$ \\
& $(16.6 \%)$ & $(90.2 \%)$ \\
L1 のみ & $2628 / 16300$ & $2446 / 2628$ \\
& $(16.1 \%)$ & $(93.1 \%)$ \\
L1+L2 & $2586 / 16300$ & $2481 / 2586$ \\
& $(15.9 \%)$ & $(95.9 \%)$ \\
\hline
\end{tabular}

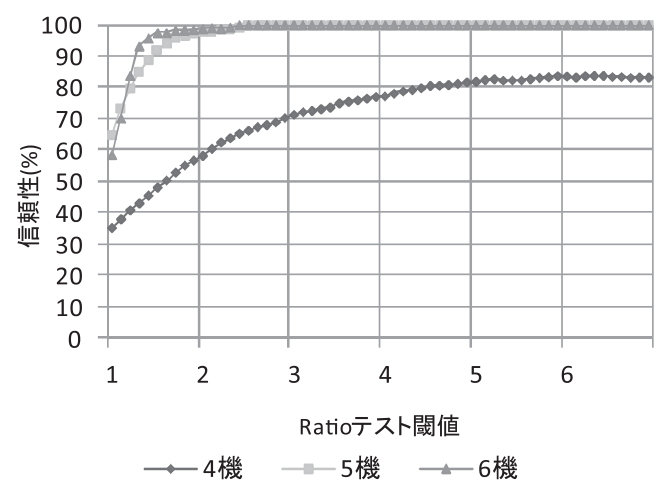

第 7 図 信頼性と Ratio テスト（マスク角 30 度，あるべき信号強度 によるチェックなし）

第 7 図より衛星数 5 機以上で測位計算を行う場合 Ratio テストの值が 3 未満であっても十分な精度が求められてい る. そのため, 衛星数を 5 機以上として測位計算をするこ とで信頼性は向上すると考えられる。一方で, 衛星数 4 機 の場合大幅に信頼性が低下していることがわかる. 衛星数 に対する信頼性の違いを 4 機の場合と 5 機以上の場合に分 
第 4 表 衛星数，マスク角別信頼性（\%)

\begin{tabular}{lcc}
\hline & マスク角 10 度 & マスク角 30 度 \\
\hline 衛星数 4 機 & $726 / 779$ & $661 / 765$ \\
& $(93.2 \%)$ & $(86.4 \%)$ \\
衛星数 5 機以上 & $1196 / 1197$ & $1820 / 1821$ \\
& $(99.9 \%)$ & $(99.9 \%)$ \\
\hline
\end{tabular}

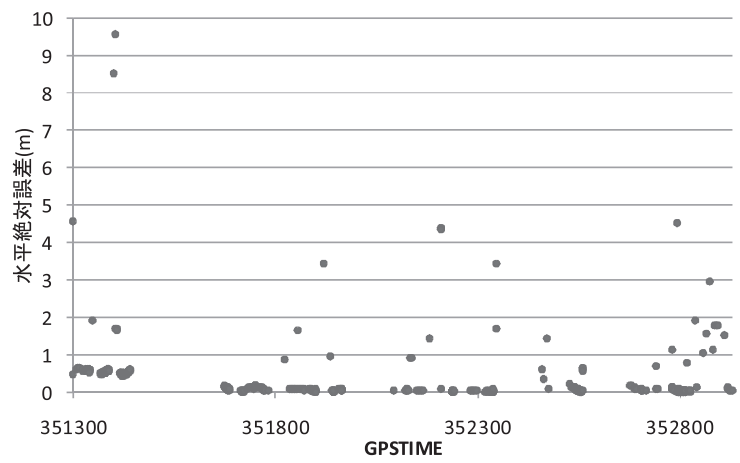

第 8 図 水平絶対誤差の推移（マスク角 10 度, あるべき信号強度に よるチェックを L1 と L2 に用いた)

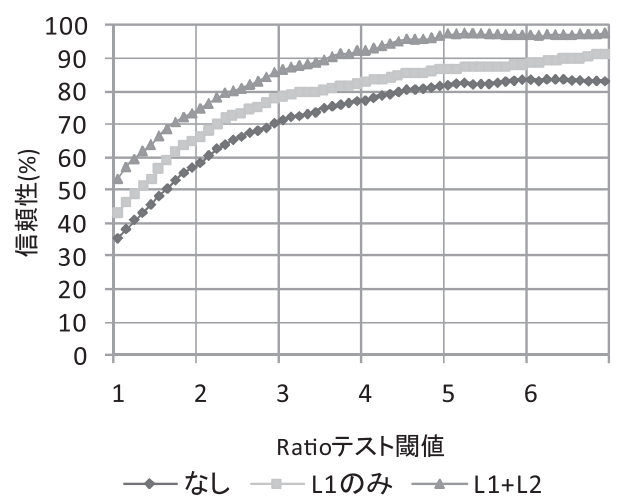

第 9 図 信頼性と Ratio テスト（マスク角 30 度，衛星数 4 機）

け，第 4 表にまとめた。ただし，L1，L2 両方に信号強度 によるチェックを利用した場合の結果である。

第 2,3 表において，マスク角 30 度で信頼性が低下した 理由は，第 4 表の結果より衛星数 4 機の場合が原因である ことがわかる.マスク角に関係なく, 衛星数 5 機以上であ れば信頼性が $99 \%$ 以上になることは注目すべきことである。 マスク角 30 度に設定した場合に 10 度と比較して利便性が 向上した理由は, 衛星数 5 機以上で FIX と判定される回 数が増加したためである。もし，衛星数 5 機以上の場合の み信頼性の高い結果として利用するのであればマスク角 30 度の場合の方が信頼性も利便性も高くなる。

第 8 図に，マスク角 10 度，あるべき信号強度によるチェッ クを L1 带と L2 带の双方に用いた場合の水平絶対誤差の推 移を参考に示した．図よりわかるように $1 \mathrm{~m}$ から $2 \mathrm{~m}$ の間 の誤差が多く見られ， $2 \mathrm{~m}$ を超す誤差は数力所見られた。

さらに，マスク角 30 度，衛星数 4 機の場合について，あ るべき信号強度によるチェックをL1帯のみに用いた場合と L1 带と L2 带の双方に用いた場合，利用しなかった場合の 信頼性と Ratio テストの関係を第 9 図にまとめた.

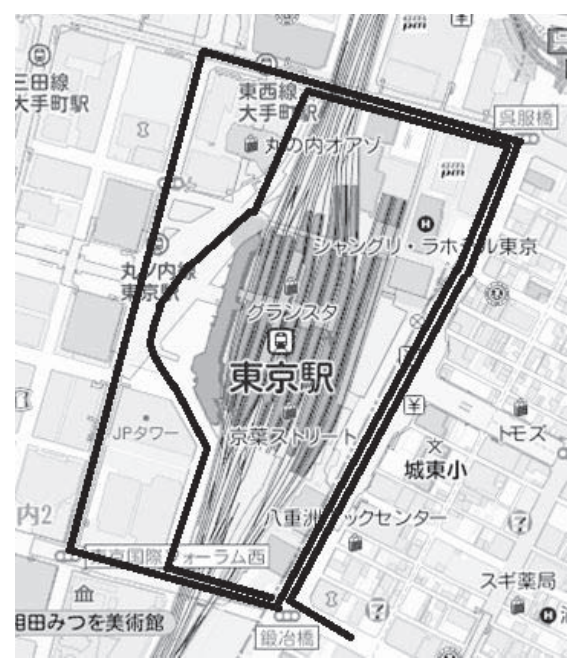

第 10 図 東京駅周辺での走行経路概要

第 5 表 マスク角 10 度の場合

\begin{tabular}{|c|c|c|}
\hline $\begin{array}{c}\text { あるべき信号強度による } \\
\text { チェック利用信号 }\end{array}$ & 利便性 & 信頼性 \\
\hline なし & $\begin{array}{c}936 / 4523 \\
(20.7 \%)\end{array}$ & $\begin{array}{l}885 / 936 \\
(94.6 \%)\end{array}$ \\
\hline L1 のみ & $\begin{array}{c}949 / 4523 \\
(21.0 \%)\end{array}$ & $\begin{array}{l}909 / 949 \\
(95.8 \%)\end{array}$ \\
\hline $\mathrm{L} 1+\mathrm{L} 2$ & $\begin{array}{c}999 / 4523 \\
(22.1 \%) \\
\end{array}$ & $\begin{array}{l}950 / 999 \\
(95.1 \%) \\
\end{array}$ \\
\hline \multicolumn{3}{|c|}{ 第 6 表 マスク角 30 度の場合 } \\
\hline $\begin{array}{c}\text { あるべき信号強度による } \\
\text { チエック利用信号 }\end{array}$ & 利便性 & 信頼性 \\
\hline なし & $\begin{array}{c}1008 / 4523 \\
(22.3 \%)\end{array}$ & $\begin{array}{c}956 / 1008 \\
(94.8 \%)\end{array}$ \\
\hline L1 のみ & $\begin{array}{c}1051 / 4523 \\
(23.2 \%)\end{array}$ & $\begin{array}{c}956 / 1051 \\
(91.0 \%)\end{array}$ \\
\hline $\mathrm{L} 1+\mathrm{L} 2$ & $\begin{array}{c}1049 / 4523 \\
(23.2 \%)\end{array}$ & $\begin{array}{c}960 / 1049 \\
(91.5 \%)\end{array}$ \\
\hline
\end{tabular}

第 9 図から信号強度のチェックを厳しくすることで衛星 数 4 機の場合においても Ratio テストによる判定が正し く行われ，信頼性が向上することがわかる．このことから Ratio テストの閾値に対する信頼性の值は観測データの品 質チェックを厳しくするほど改善されることがわかる。ま た，この時の FIX 解 (Ratio の值が 3 以上) の平均可視衛 星数は，あるべき信号強度によるチェックを L1 带と L2 带 の双方に用いた場合で 4.87 機，利用しなかった場合で 5.01 機であった。

4.2 丸の内周辺実験 2010 年 10 月 25 日, 東京駅周辺 を車で走行し, $4 \mathrm{~Hz}$ で 20 分程度 GPS デー夕を取得した。 受信機は基準局と車側ともに 2 周波の高精度受信機で基線 長は $2 \mathrm{~km}$ 程度であった。第 10 図に走行経路を示した. 真 值として前述の POSLV を利用した。

第 $5 ， 6$ 表に結果を示す．表の見方は第 1 表と同様であ る。また，第 11 眓にマスク角 30 度，あるべき信号強度に よるチェックを L1, L2 両方に利用した場合の衛星数ごと の信頼性を示す. 図の見方は第 3 図と同様である. 


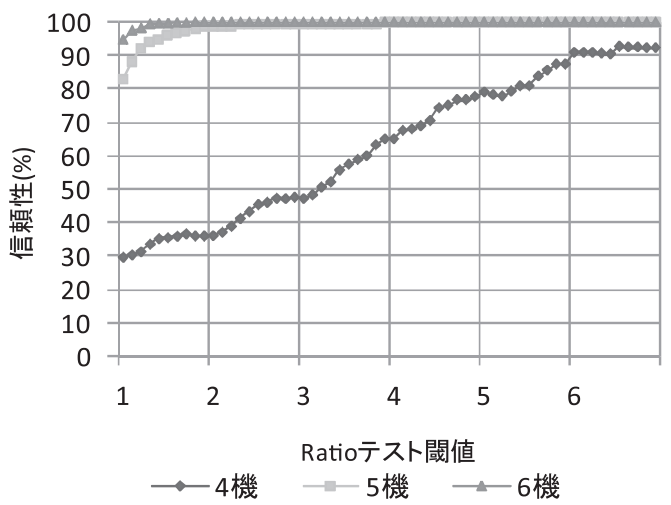

第 11 図 信頼性と Ratio テスト（マスク角 30 度，L1，L2 に利用）

第 7 表 衛星数, マスク角別信頼性（\%)

\begin{tabular}{lcc}
\hline & マスク角 10 度 & マスク角 30 度 \\
\hline 衛星数 4 機 & $87 / 134$ & $78 / 165$ \\
& $(64.9 \%)$ & $(47.3 \%)$ \\
衛星数 5 機以上 & $863 / 865$ & $882 / 884$ \\
& $(99.8 \%)$ & $(99.8 \%)$ \\
\hline
\end{tabular}

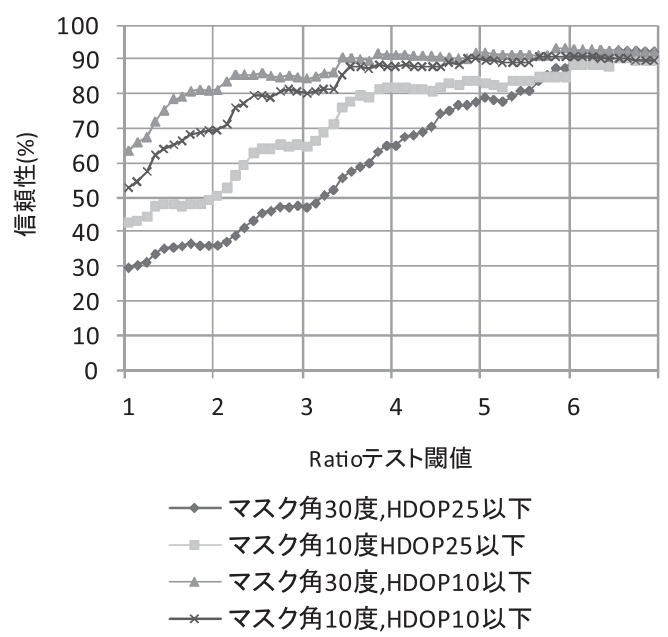

第 12 図 信頼性と Ratio テスト（マスク角 30 度，L1，L2 に利用）

第 5，6 表より名古屋での実験同様，マスク角 30 度より マスク角 10 度の方が信頼性が高い. また, あるべき信号 強度によるチェックを行わない方が信頼性が高くなる場合 も見られた。このようになった理由は名古屋実験と同様に， 第 11 図からもわかるように衛星数 4 機の場合の Ratio テ ストの信頼度がきわめて低かったためである、マスク角や 信号強度チェックにより衛星数に対する信頼性の違いを 4 機の場合と 5 機以上の場合に分け，第 7 表にまとめた。た だし，L1，L2 両方に信号強度によるチェックを利用した場 合の結果である。

第 12 図から HDOP 25 以下ではマスク角 30 度の場合の 方が 10 度に比べ信頼性が低いが, HDOP 10 以下ではその 関係が反対になっていることがわかる。、マスク角 30 度に設 定する場合, 衛星配置によるチェックも厳しくする必要が あるといえる。

4.3 月島駅周辺実験 2010 年 10 月 25 日, 月島駅周辺 を車で走行し， $4 \mathrm{~Hz}$ で 20 分程度 GPS デー夕を取得した。

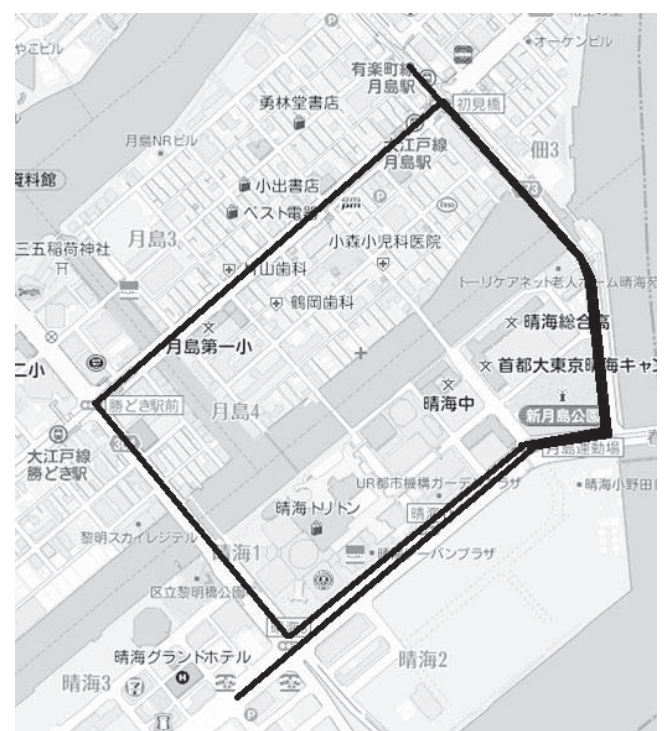

第 13 図 月島駅周辺での走行経路概要

第 8 表 マスク角 10 度の場合

\begin{tabular}{ccc}
\hline $\begin{array}{c}\text { あるべき信号強度による } \\
\text { チェック利用信号 }\end{array}$ & 利便性 & 信頼性 \\
\hline なし & $1877 / 4996$ & $1840 / 1877$ \\
& $(37.6 \%)$ & $(98.0 \%)$ \\
L1 のみ & $2107 / 4996$ & $2072 / 2107$ \\
& $(42.2 \%)$ & $(98.3 \%)$ \\
L1+L2 & $2402 / 4996$ & $2384 / 2402$ \\
& $(48.1 \%)$ & $(99.3 \%)$ \\
\hline
\end{tabular}

第 9 表 マスク角 30 度の場合

\begin{tabular}{ccc}
\hline $\begin{array}{c}\text { あるべき信号強度による } \\
\text { チェック利用信号 }\end{array}$ & 利便性 & 信頼性 \\
\hline なし & $1850 / 4996$ & $1772 / 1850$ \\
& $(37.0 \%)$ & $(95.8 \%)$ \\
L1 のみ & $1822 / 4996$ & $1786 / 1822$ \\
& $(36.5 \%)$ & $(98.0 \%)$ \\
L1+L2 & $1795 / 4996$ & $1771 / 1795$ \\
& $(35.9 \%)$ & $(98.7 \%)$ \\
\hline
\end{tabular}

受信機は基準局と車側ともに 2 周波の高精度受信機で基線 長は $2 \mathrm{~km}$ 程度であった。片側 2 車線ある. 真值として名 古屋駅周辺と同様にPOSLV を利用した。第 13 図に走行 経路を示した。

第 8,9 表に結果を示す．表の見方は第 1 表と同様であ る。また，第 14 図にマスク角 10 度，あるべき信号強度に よるチェックを L1，L2 両方に利用した場合の衛星数ごと の信頼性を示す．図の見方は第 3 図と同様である.

第 8,9 表の結果より, 名古屋, 丸の内実験と異なり, マ スク角 30 度の場合の方が利便性, 信頼性ともに低いこと がわかる. 第 10 表にマスク角や信号強度チェックにより衛 星数に対する信頼性の違いを 4 機の場合と 5 機以上の場合 に分け，まとめた，ただし，L1，L2 両方に信号強度による チェックを利用した場合の結果である。

名古屋，丸の内実験と異なる点はマスク角を高く設定し たことにより, 衛星数 5 機以上の場合の FIX 回数が減り, 


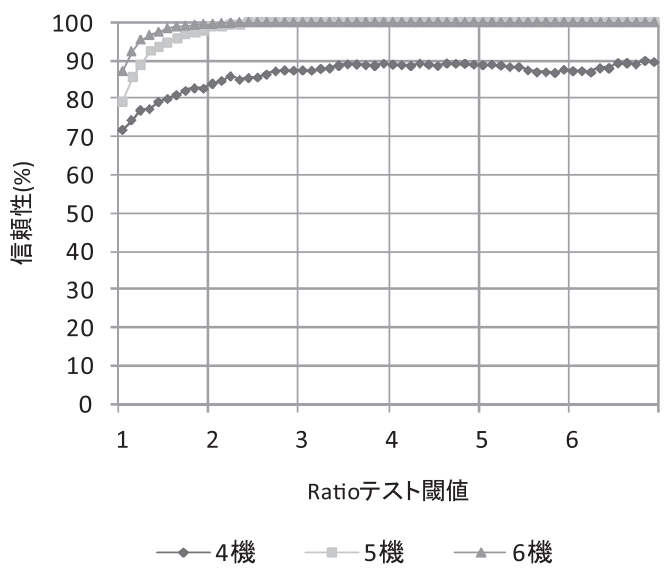

第 14 図 信頼性と Ratio テスト（マスク角 10 度，L1，L2 に利用）

第 10 表 衛星数, マスク角別信頼性 (\%)

\begin{tabular}{lcc}
\hline & マスク角 10 度 & マスク角 30 度 \\
\hline 衛星数 4 機 & $126 / 144$ & $1270 / 1293$ \\
& $(87.5 \%)$ & $(98.2 \%)$ \\
衛星数 5 機以上 & $2258 / 2258$ & $501 / 502$ \\
& $(100 \%)$ & $(99.8 \%)$ \\
\hline
\end{tabular}

4 機の場合の FIX 回数が増加しているところである. 衛星 数 4 機の FIX 回数がマスク角 10 度では 144 回に対し，マ スク角 30 度では 1293 回に増加している。この結果から名 古屋ほど高層ビルが立ち並んでいない月島のような環境で は, マスク角 $10 \sim 15$ 度でも良い品質の電波が届いている と考えられる。

4.4 考察 第 15 図に測位環境の異なる名古屋, 丸の内, 月島での衛星数 4 機の場合の信頼性と Ratio テストの值の 関係を示した. 3 力所とも同じ条件の結果で L1, L2 両方 にあるべき信号強度によるチェックを利用し，マスク角 30 度で HDOP 25 以下の結果である。第 15 図と同じ条件で 第 16 図に利便性とRatio テストの值の関係を示した。た だし，利便性を示しているため，衛星数は 4 機の場合に限 らない。

3 つの実験結果を通してわかるように，測位環境によっ て衛星数 4 機の場合でも信頼性は大きく異なる。また, 品 質チェックを厳しくすることによっても同様で，厳しくする ほど信頼性の高い結果を得ることができ，品質チェックを甘 くするほど信頼性を損なう結果となる。衛星数 5 機以上で あれば，非常に高い信頼性を維持することができることも 確証された。また利便性について着目すると, RTK-GPS の場合, 品質チェックを甘くすると, 使用衛星数が増加する が，FIX 解が減少する事象が見られた。これは RTK-GPS で利用されている LAMBDA 法と Ratio テストのセット が，観測データの誤差，特にバイアスに敏感であることが 挙げられる。よって, 品質の悪い衛星が混ざるよりは, 品 質の良い衛星を選択することが極めて重要であるといえる. また近未来の GNSS の環境を想定した場合，使用衛星数が 増加する方向にあるため, 本論文で提案した, 簡便な品質 チェックアルゴリズムが重要になると予想される。

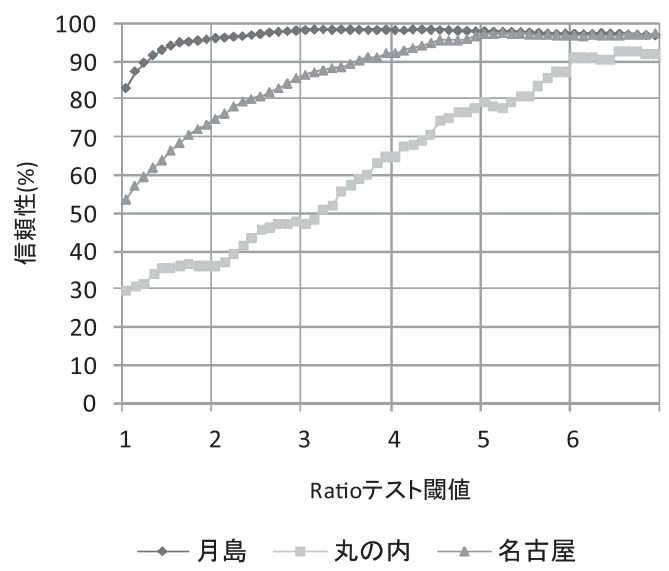

第 15 図 信頼性と Ratio テスト (L1，L2 に利用，マスク角 30 度)

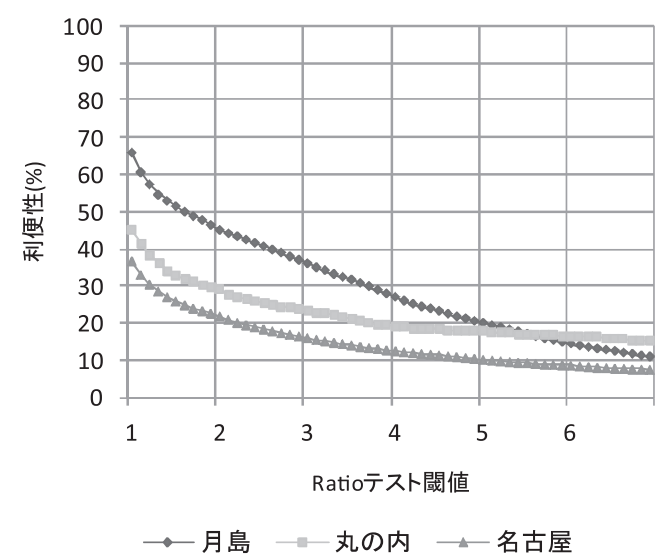

第 16 図 利便性と Ratio テスト（L1，L2 に利用，マスク角 30 度）

\section{5. ま と め}

都市部において, 衛星数 5 機以上ならば, Ratio テスト の值が 3 以上の結果は十分な信頼性が得られる。また， Ratio テストの值が 3 未満であっても信頼性が高いことがわ かった。 それに反して衛星数 4 機の場合, 測位環境や品質 チェックの厳しさによって信頼性が変化することがわかっ た. チェックを厳しくすることでHDOP が増加してしまう ことには注意する必要がある。

1 つの方法として, 地図のデータベース上で建物の高さ を区分けし，アルゴリズムを変更することが挙げられるが, 基本的には衛星数 4 機の場合は, 都市部移動体では使用を 避けたほうが良いことが，本研究よりわかった。

また，本研究で提案した複数周波数間での品質チェック が高精度測位に有効であることも確認できた。 今後, 衛星 数が増加し， 2 周波だけでなく 3 周波の信号が利用できる ようになることから，品質の悪い信号を高い信頼性で見分 けることがより重要になると思われる。

本稿の移動体実験に際して，レファレンスとなる貴重な 位置データを提供して頂いた豊田中央研究所殿に深く感謝 します。 


\section{参 考 文 献}

1) Teunnissen, P. J. G.: The Least-Square Ambiguity Decorrelation Adjustment: A Method for Fast GPS Integer Ambiguity Estimation, J. Geodesy., 70, 1-2 (1995), pp. 65-82.

2) Teunnissen, P. J. G. and Verhagen, S.: On GNSS Ambiguity Acceptance Tests, Proceedings of IGNSS Symposium 2007, Sydney, 2007.

3) Alfred, L.: GPS Satellite Surveying, 2nd ed., John Wiley and Sons, New York, 1995, pp. 368-371.
4) POSLV, http://www.applanix.com/products/land/pos-lv.html

5) Misra, P. and Enge, P. : 精通 GPS (改訂第 2 版), 測位航法学 会, 東京, 2010, pp. 234-235.

6) Kubo, N., Yasuda, A. and Shibazaki, R.: An Effective Multipath Mitigation Technique under Strong Multipath Environments, The 2005 International Symposium on GPS/GNSS, Hong Kong, 2005.

7) Lehner, A. and Steingass, A.: A Novel Channel Model for Land Mobile Satellite Navigation, ION2005, 2005. 